\title{
Exploration on Pre Sowing Seed Invigoration with Growth Regulators on Germination of Small Onion (Allium cepa var. aggregatum)
}

\author{
P. Sujanthiya ${ }^{1 *}$, V. Swaminathan ${ }^{1}$, R. Arunkumar ${ }^{1}$ and T. Siva Kumar ${ }^{2}$ \\ ${ }^{1}$ Department of Horticulture, Agricultural College and Research Institute, Tamil Nadu \\ Agricultural University, Madurai, India \\ ${ }^{2}$ Department of Plant Physiology, Agricultural College and Research Institute, Tamil Nadu \\ Agricultural University, Madurai, India \\ *Corresponding author
}

\section{A B S T R A C T}

\begin{tabular}{|l|}
\hline Ke y w o r d s \\
Onion, Seed, \\
$\begin{array}{l}\text { Priming, GA } \\
\text { Germination }\end{array}$ \\
\hline Article Info \\
\hline $\begin{array}{l}\text { Accepted: } \\
\text { 15 July } 2020 \\
\text { Available Online: } \\
\text { 10 August } 2020\end{array}$ \\
\hline
\end{tabular}

\begin{abstract}
Small onion (Allium cepa var. aggregatum) is a popular Rabi bulb vegetable in the peninsular India. It is propagated by both seed and bulb. Hence experiment was conducted to study the effect of seed priming on small onion var. Co (On) -5 . The experiment was laid out in Completely Randomized Design (CRD) with two replications. Onion seeds were primed with following priming agents such as $\mathrm{GA}_{3}$, NAA, water at different concentration $(50 \mathrm{ppm}, 100 \mathrm{ppm})$ and different time periods $(12,18,24 \mathrm{hrs})$. Data was recorded on germination percentage, shoot length, root length and vigour index. The experimental findings revealed that, seeds primed with $\mathrm{GA}_{3} 100 \mathrm{ppm}$ for $12 \mathrm{hrs}$ showed higher germination percentage (69.50 to $94 \%$ ), shoot length $(7.02$ to $9.44 \mathrm{~cm})$, root length (5.01 to $6.91 \mathrm{~cm}$ ) and Vigour index I (696.69 to 1630.44 ) over control, respectively. Seeds treated with $\mathrm{GA}_{3} 100 \mathrm{ppm}$ for $12 \mathrm{hrs}$ produced vigorous seedling with good root system which results in earlier transplanting of seedling by 9 days.
\end{abstract}

\section{Introduction}

Onion (Allium cepa L.) belongs to the family Alliaceae is the second most valuable vegetable crop grown throughout the world. It is rightly called the "queen of the kitchen" (Selvaraj, 1976) and cultivated in several regions of the world. India, the second largest producer of onion in the world followed by China, ranks third in export next to Netherlands and Spain. India exported 24lakh MT of fresh onion to other countries worth of Rs. 3106.50 crores (APEDA, 2017). Bulb used for edible purpose contains volatile oil known as allyl propyl disulphide $\left(\mathrm{C}_{6} \mathrm{H}_{12} \mathrm{~S}_{2}\right)$ which is responsible for pungency. Onion is widely used in all parts of world as a flavouring agent among the vegetables. It is used as salad and in curries as boiled, fried and for making soups and pickles. Onion is also processed as dehydrated powder, rings and shreds.

Every $100 \mathrm{~g}$ of edible portion of bulb contains $86.69 \mathrm{~g}$ moisture, $1.2 \mathrm{~g}$ protein, $0.1 \mathrm{~g}$ fat, $11.1 \mathrm{~g}$ carbohydrate, 50kcal energy, $47 \mathrm{mg}$ calcium, 
$0.7 \mathrm{~g}$ iron, $\quad 0.08 \mathrm{mg}$ thiamine, $\quad 0.01 \mathrm{mg}$ riboflavin, and $11 \mathrm{mg}$ Vit. C (Fageria et al., 2006). The onion has effective germicidal properties. It acts as stimulant, reduces cough, used as remedy for tuberculosis, leprosy, piles, swelling and blood impurities.

Due to the huge post harvest loss in bulb storage, the seeds are popular among the farming community. However the transplants require 40 days in nursery. This increase the cropping season upto 130 days.

Small onion is an open pollinated crop, the germination percent is low. Seedlings need six weeks for transplanting and the total duration of the crop is of four months. The farmers harvest the bulbs earlier to get higher price per unit area. But earlier the harvest smaller the yield resulted by immature cropping. Instead of early harvest seedlings need to be transplanted earlier to minimise the duration.

Early transplanting of seedlings can be affected by seed priming treatments that accelerates the germination and seedling growth in most of the crops under normal and stress conditions (Finch et al., 2004).

Pre-sowing treatments affects the pregermination metabolic activities while enhancing the germination. Hence the present study was undertaken to study the effect of growth regulators on seed growth parameters.

\section{Materials and Methods}

The experiment was laid out in Completely Randomized Design (CRD) with two replications and conducted at Department of Horticulture, AC \& RI, Madurai. Seeds of Co (On) -5 having a minimum germination of 70 percent were subjected to 16 pre-sowing invigoration seed treatments.

\section{Seed Treatments}

The seeds were soaked in growth regulators solutions $\left(\mathrm{GA}_{3}\right.$ and NAA) in different concentration and durations. Table 1 includes the details of seed treatments imposed.The treated seeds were shade dried at room temperature $\left(28 \pm 2^{\circ} \mathrm{C}\right)$ to bring its original moisture content.

The germination test was conducted using roll towel paper method as per ISTA procedure. The laboratory observation on germination percentage, length of shoot $(\mathrm{cm})$, length of root $(\mathrm{cm})$ and vigour. index were recorded on $14^{\text {th }}$ day of sowing The data obtained from various treatments were analysed statistically adopting the procedure described by (Panse and Sukatme, 1985).

\section{Results and Discussion}

Significant differences were observed in all the treatments. Among the treatments, $\mathrm{GA}_{3}$ $100 \mathrm{ppm}$ significantly increased the germination percentage, shoot length $(\mathrm{cm})$, root length $(\mathrm{cm})$ and Vigour index of the seedlings (Table 2).

The germination percentage ranged from 69.50 to $94 \%$ (Figure 1). $\mathrm{GA}_{3}$ role in breaking the dormancy, promoting earlier and uniform germination may be the reason for enhanced germination percentage (Thejeshwini et al., 2018).

$\mathrm{GA}_{3}$ plays a major role in in seed germination through a-amylase synthesis which converts the stored starch into sugar by respiration of cells (Finch-Savage and Leubner, 2006). Similar findings were supported by Hiroshi and Thimann (1960) in lettuce, Maurya and Lal (1972) in onion, Vanangamudi et al., (1988), Balaguera et al., (2009) in tomato, Das et al., (2014), Agung and diara (2017). 
Table.1 Treatment details

\begin{tabular}{|c|l|}
\hline Treatment Name & \multicolumn{1}{|c|}{ Treatments used } \\
\hline $\mathbf{T}_{\mathbf{1}}$ & $\mathrm{GA}_{3} 50 \mathrm{ppm}+12 \mathrm{hrs}$ \\
\hline $\mathbf{T}_{\mathbf{2}}$ & $\mathrm{GA}_{3} 50 \mathrm{ppm}+18 \mathrm{hrs}$ \\
\hline $\mathbf{T}_{\mathbf{3}}$ & $\mathrm{GA}_{3} 50 \mathrm{ppm}+24 \mathrm{hrs}$ \\
\hline $\mathbf{T}_{\mathbf{4}}$ & $\mathrm{GA}_{3} 100 \mathrm{ppm}+12 \mathrm{hrs}$ \\
\hline $\mathbf{T}_{\mathbf{5}}$ & $\mathrm{GA}_{3} 100 \mathrm{ppm}+18 \mathrm{hrs}$ \\
\hline $\mathbf{T}_{\mathbf{6}}$ & $\mathrm{GA}_{3} 100 \mathrm{ppm}+24 \mathrm{hrs}$ \\
\hline $\mathbf{T}_{\mathbf{7}}$ & NAA 50ppm $+12 \mathrm{hrs}$ \\
\hline $\mathbf{T}_{\mathbf{8}}$ & NAA 50ppm $+18 \mathrm{hrs}$ \\
\hline $\mathbf{T}_{\mathbf{9}}$ & NAA 50ppm $+24 \mathrm{hrs}$ \\
\hline $\mathbf{T}_{\mathbf{1 0}}$ & NAA 100ppm $+12 \mathrm{hrs}$ \\
\hline $\mathbf{T}_{\mathbf{1 1}}$ & NAA 100ppm $+18 \mathrm{hrs}$ \\
\hline $\mathbf{T}_{\mathbf{1 2}}$ & NAA 100ppm $+24 \mathrm{hrs}$ \\
\hline $\mathbf{T}_{\mathbf{1 3}}$ & Water $+12 \mathrm{hrs}$ \\
\hline $\mathbf{T}_{\mathbf{1 4}}$ & Water $+18 \mathrm{hrs}$ \\
\hline $\mathbf{T}_{15}$ & Water $+24 \mathrm{hrs}$ \\
\hline $\mathbf{T}_{\mathbf{1 6}}$ & Dry seed (control) \\
\hline
\end{tabular}

Table.2 Effect of seed priming on co (on) -5

\begin{tabular}{|c|c|c|c|c|}
\hline Treatments & Germination percentage (\%) & Shoot length (cm) & Root length (cm) & Vigour Index I \\
\hline $\mathbf{T}_{\mathbf{1}}$ & 86.50 & 8.26 & 6.02 & 1270.87 \\
\hline $\mathbf{T}_{\mathbf{2}}$ & 82.50 & 8.80 & 5.35 & 1245.15 \\
\hline $\mathbf{T}_{\mathbf{3}}$ & 86.00 & 7.82 & 5.62 & 1202.04 \\
\hline $\mathbf{T}_{\mathbf{4}}$ & 94.00 & 9.44 & 6.91 & 1630.44 \\
\hline $\mathbf{T}_{\mathbf{5}}$ & 85.50 & 8.36 & 5.63 & 1290.80 \\
\hline $\mathbf{T}_{\mathbf{6}}$ & 80.50 & 8.42 & 5.84 & 1147.53 \\
\hline $\mathbf{T}_{\mathbf{7}}$ & 85.00 & 8.29 & 5.64 & 1192.16 \\
\hline $\mathbf{T}_{\mathbf{8}}$ & 81.00 & 8.37 & 5.14 & 1094.93 \\
\hline $\mathbf{T}_{\mathbf{9}}$ & 84.00 & 7.55 & 4.89 & 1044.96 \\
\hline $\mathbf{T}_{\mathbf{1 0}}$ & 82.00 & 8.42 & 5.08 & 1106.96 \\
\hline $\mathbf{T}_{\mathbf{1 1}}$ & 79.50 & 8.34 & 4.04 & 983.73 \\
\hline $\mathbf{T}_{\mathbf{1 2}}$ & 83.50 & 8.06 & 4.85 & 1078.03 \\
\hline $\mathbf{T}_{\mathbf{1 3}}$ & 78.50 & 8.04 & 4.28 & 1024.51 \\
\hline $\mathbf{T}_{\mathbf{1 4}}$ & 76.50 & 7.99 & 3.90 & 947.04 \\
\hline $\mathbf{T}_{\mathbf{1 5}}$ & 79.00 & 7.63 & 4.04 & 922.11 \\
\hline $\mathbf{T}_{\mathbf{1 6}}$ & 69.50 & 7.02 & 2.99 & 696.26 \\
\hline $\mathbf{M E A N}_{\mathbf{S . E d}}$ & $\mathbf{8 2 . 0 9}$ & $\mathbf{8 . 1 7}$ & $\mathbf{5 . 0 1}$ & $\mathbf{1 0 8 9 . 5 0}$ \\
\hline $\mathbf{C D}(\mathbf{0 . 0 5}$ & $\mathbf{2 . 9 2}$ & $\mathbf{0 . 2 1}$ & $\mathbf{5 . 4 0}$ & $\mathbf{5 4 . 2 8}$ \\
\hline & $\mathbf{6 . 1 9}$ & $\mathbf{0 . 4 4}$ & $\mathbf{1 1 5 . 0 8}$ \\
\hline
\end{tabular}


Fig1 Effect of seed priming on germination percentage of onion

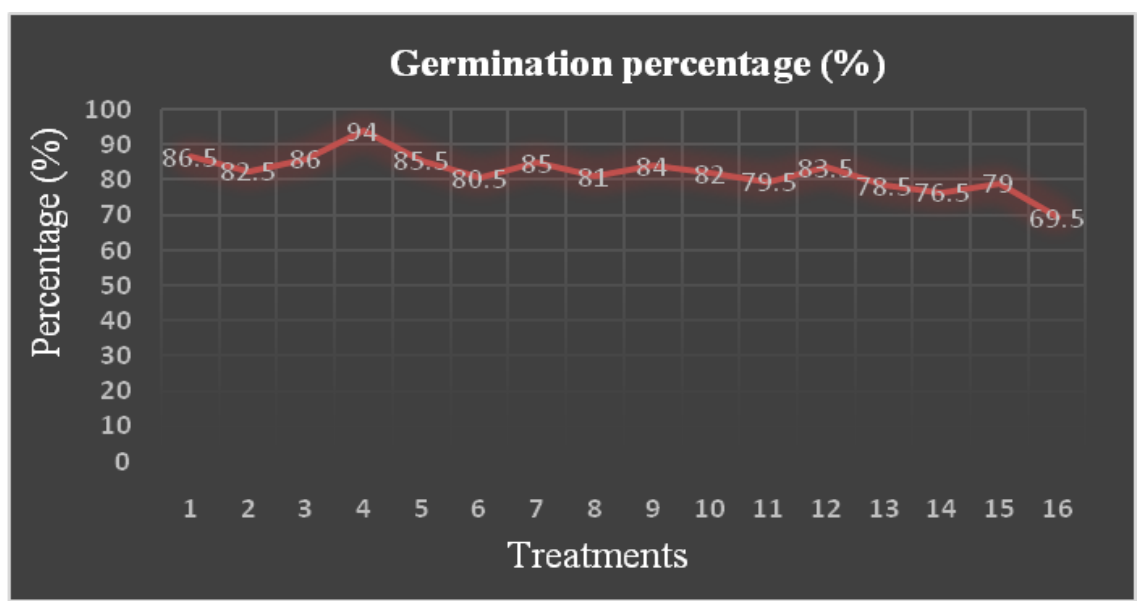

Fig.2 Effect of seed priming on Vigour Index of onion

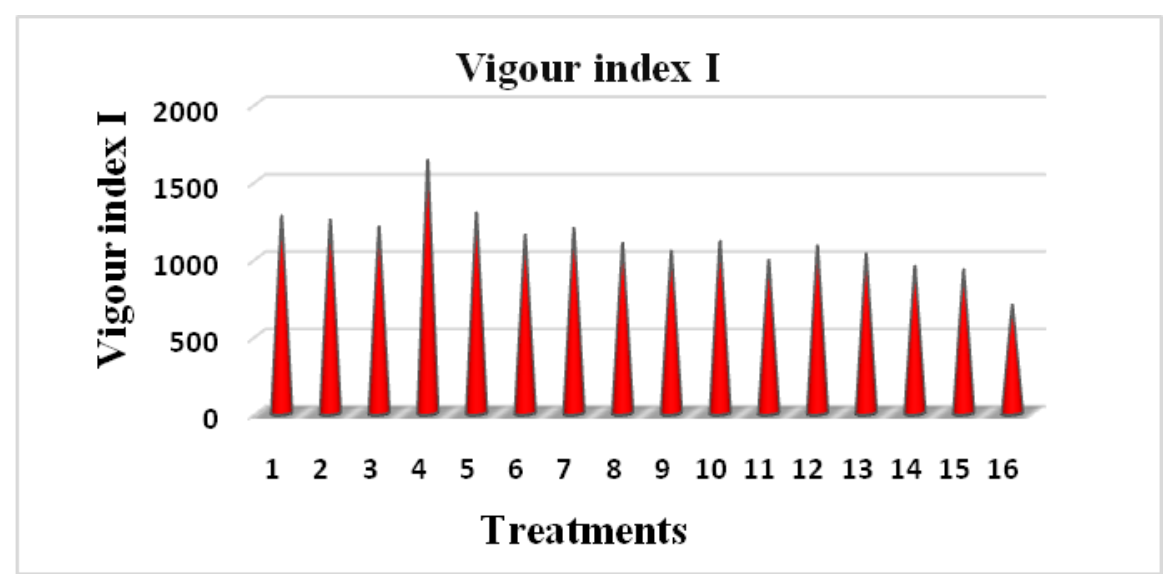

The length of shoot and vigour index was observed to be higher in $\mathrm{GA}_{3}$ at $100 \mathrm{ppm}$ soaked for $12 \mathrm{hrs}$ followed by $\mathrm{GA}_{3} 50 \mathrm{ppm}$ for $12 \mathrm{hrs}$ (Table 2). $\mathrm{GA}_{3}$ mainly promotes cell elongation and also contributes to seedling length. $\mathrm{GA}_{3}$ also shows positive influence on photosynthetic activity in the plants. Similar results were observed by Demir et al., (1994) in egg plant, Demir and Van de Venter (1999) on watermelon, Yarnia and Tabirizi (2012) in onion. The seedling vigour index was increased from 696.69 to 1630.44 . Higher seedling vigour is due to high respiration rate, metabolic activity and better translocation of metabolites to the growing point (Figure 2). Higher seedling vigour index is an indicator of the ability of the seedlings to survive under unfavorable condition (Agung and Diara, 2017). Similar results were supported by Vanangamudi et al., (1988) in onion, Yogananda et al., (2004) in bell pepper, Balaguera et al., (2009) in tomato, Kumar and Singh (2013) in bittergourd, Vinayak et al., (2017) in ridgegourd and summer squash.

In conclusion on the basis of the results obtained from the present investigation, it could be considered that pre sowing seed treatment with $\mathrm{GA}_{3}$ at $100 \mathrm{ppm}$ for $12 \mathrm{hrs}$ accomplished best results followed by $\mathrm{GA}_{3}$ $50 \mathrm{ppm}$ for $12 \mathrm{hrs}$ which improves the germination percentage, shoot length, root length and vigour index. Hence seed priming with $\mathrm{GA}_{3}$ at 100 ppm for $12 \mathrm{hrs}$ can be used 
for Co (on) 5 to increase the germination percentage and uniform germination. The seeds when treated with $\mathrm{GA}_{3}$ 100ppm for $12 \mathrm{hrs}$ will reduce the transplanting duration over untreated ones. The seedlings can be transplanted 9 days earlier than untreated seedlings. Further testing with different varieties and different media would confirm the utility of $\mathrm{GA}_{3}$ as seed primer in onion.

\section{References}

Agung, I G.A.M.S., Diara, I.W. Pre-sowing Treatment Enhance Germination and Vigour of True Shallot (Allium cepa var. aggregatum) Seeds. International Journal of Environment, Agriculture and Biotechnology (IJEAB). 2017

APEDA. Agricultural and Processed Food Products Export Development Authority, Ministry of Commerce and Industry, Government of India, 2017.

Balaguera-Lopez, H.E., Cárdenas-Hernandez, J.F. and Alvarez-Herrera, J.G. Effect gibberellic acid $\left(\mathrm{GA}_{3}\right)$ on seed germination and growth of tomato (solanum lycopersicum. Acta Horticulturae. 2009; 821, 141-148

Das, S., Dash, F.M., Nandi, A.K., Senapati, N., Sarkar, S. and Pandey, G.. Seed quality index an estimate used to predict response of bottle gourd seeds (Lagenaria siceraria (Mol.) Standl) to hydro- and osmo-priming. Advances in Applied Agricultural Science. 2014; Volume 02: 12, 01-10, 2383-4234.

Demir I and Van de Venter H A. The effect of priming treatments on the performance of watermelon (Citrullus lanatus (Thunb.) Matsum and Nakai) seeds under temperature and osmotic stress, Seed Science and Technology. 1999; 27: 871-875.

Demir, I., Ellialtioglus and Tipiradaz, R. The effect of different priming treatments on reparability of eggplant seed. Acta
Horticulture (ISHS). 1994; 362:205212.

Fageria,M.S., Choudhary, B.R. and Dhaka, R.S. Vegetable crops production technology, Vol. II, Kalyani publisher, New Delhi. 2006; pp. 223 - 227.

Finch-Savage W E, Dent KC and Clark L J. Soak conditions and temperature following sowing influence the response of maize (L.) seeds to on-farm priming (pre-sowing seed soak), Field Crops Research. 2004; 90 (2-3): 361-374.

Finch-Savage, W.E. and G. Leubner-Metzger. Seed dormancy and the control of germination. New Phytol. 2006; 171:501-523

Hiroshi Ikuma and Ke-nneth V. Thimann. Action of gibberellic acid on lettuce seed germination. Plant physiology. pp. $557-566$.

Journal of research, Punjab Agriculture University, 2013; 50 (3\&4):114-118.

Kumar R and Singh R. Effect of priming on emergence and vigour of bittergourd.

Maurya AN and Lal S. Effect of plant regulators on the germination on onion (Allium cepa L.) seeds, Punjab Horticultural Journal. 1972; 12: 257259.

Panse V.G. Sukhatme. Statistical methods for agricultural workers. Indian Council of Agriculture Research, New Delhi. 1985; 134-192.

Selvaraj S. Queen of kitchen, Kisan World. 1976. 3(12):32-34.

Thejeshwin B, Manohar Rao A, Razia Sultana and Hanuman Nayak M. 2018. On farm pre-sowing invigoration seed treatments in onion (Allium cepa L.). Journal of Pharmacognosy and Phytochemistry. 7(5): 3354-3357

Vanangamudi K, Kalavathi D, Ramamoorthy K. 1988. Effect of gibberellic acid on dormancy, flowering, bulb and seed production in Bellary onion (Allium cepa L.). Indian Journal of Plant 
Physiology. 31:190-92.

Vinayak, K. Babanpreet, K. Snehdeep, S. and Navdeep, G. Effect of Seed Priming with $\mathrm{GA}_{3}$ and $\mathrm{KNO}_{3}$ on Nursery Raising of Ridge Gourd (Luffa acutangula) and Summer Squash (Cucurbita pepo). International conference on recent innovations in science, agriculture, engineering and management. 2017. pp: $682-688$.

Yarnia, M. and Tabrizi E.F.M. 2012. Effect of seed priming with different concentration of GA3, IAA and Kinetin on Azarshahr onion germination and seedling growth. Journal of Basic and Applied Scientific Research. 2(3): 26572661.

Yogananda, D.K., Vyakaranahal, B.S. and Shekhargouda, M. 2004. Effect of seed invigouration with growth regulators and micronutrients on germination and seedling vigour of bell pepper cv. California wonder. Karnataka Journal of Agriculture Sciences.17(4):811-813.

\section{How to cite this article:}

Sujanthiya, P., V. Swaminathan, R. Arunkumar and Siva Kumar, T. 2020. Exploration on Pre Sowing Seed Invigoration with Growth Regulators on Germination of Small Onion (Allium cepa var. aggregatum). Int.J.Curr.Microbiol.App.Sci. 9(08): 1219-1225. doi: https://doi.org/10.20546/ijcmas.2020.908.136 